\title{
Comparative Analysis of Education in Some Areas of Latin America, Africa and China
}

\author{
Zhang Hanshu
}

\author{
Nanhang Jincheng College, Nanjing, Jiangsu, 211156, China, \\ *Corresponding author. Email: gaoming@cas-harbour.org
}

\begin{abstract}
Since the start of the fight against poverty in China, solving the problem of education in remote and poor areas has always been a major focus of China's work. However, due to the geographical environment, conservative idea of locals and other reasons, it is difficult to solve the problem of education in remote and poor areas. After analyzing and collecting relevant data of education policies in China and some nations of Africa and Latin America, it was founded that there are four factors include faculty, funding, school and idea, are mainly involved in the education of remote and poor areas. Based on the experience of these countries in the implementation of educational policies, this paper will provide suggestions for national education policies based on the above four factors.
\end{abstract}

Keywords: Education, public policy, China, Latin America, Africa

\section{INTRODUCTION}

Recently, a large amount of research has been focused on a period of education, such as primary or secondary education, or on education in a particular place, such as a school or even a class. These studies can dig into the details of education, but often lack a macro analysis of educational issues. Therefore, this paper analyzes the implementation of educational policies in different countries and the impact of their success or failure from a macro perspective. The education policy in this paper is mainly about improving education in remote and poor areas, because this issue has been widely concerned in the world today: the United Nations has proposed that the problem of education in remote areas should not be ignored, and China has also put forward the slogan of "developing education in remote areas to alleviate poverty". Besides, this issue involved two questions: what can we learn from the policies that carried out before? and what can we do to solve the problems of education in remote and poor areas? By solving these questions through qualitative research, experience can be learned from the difficulties that the countries faced and countermeasures they carried out before, then a reference role can be provided for governments.

\section{EDUCATION STATUS AND POLICY ANALYSIS}

\subsection{Take some areas of China as an example}

\subsubsection{Education in some areas of China}

Since China's reform and open, China has made overall excellent progress in education popularization. The net enrollment rate of primary school-age children has reached $99.95 \%$, the gross enrollment rate of junior middle school students has reached $100.9 \%$, and the consolidation rate of nine-year compulsory education has reached $94.2 \%$. Those relevant indicators have reached the average level of high-income countries in the world [1].

However, it is undeniable that students still drop out of school in some areas due to geographical reasons, economic condition, conservative ideas and other reasons. Although Article 2 of the compulsory education law of the People's Republic of China issued by the central government in 1986 clearly stipulates that "the State implements a nine-year compulsory education system. Compulsory education is an education that all school-age children and adolescents must receive and a public welfare undertaking that the state must guarantee. Compulsory education shall be implemented without tuition and miscellaneous fees. The state establishes a 
mechanism to guarantee the funds for compulsory education to ensure the implementation of the compulsory education system. "[2] However, in remote and poor areas that are difficult to supervise, guarantee of absolute implementation is still hard to realize.

What is more, the backwardness of education in remote areas is not just the lack of material conditions. In recent decades, it is very common for migrant workers in remote areas to work in big cities in China. In some villages, almost all middle-aged people go to work in other cities, leaving their children to the elderly. Among these old people, there are many conservative people who think that only boys need education and girls do not, or they do not care much about education. In the end, it is easy for children to miss appropriate education, especially family education. Unless ideas of those people can be changed, the process of education in remote areas will become a constant problem. Moreover, for example, the education situation in a small village, Taihang mountain area, China is still less than satisfactory. "Learning a few words and then cultivating fields with parents" is a tradition that residents in this area have adhered to for generations. Such a shallow level of Education is not enough to send these children living in mountainous areas to colleges and universities. In the long run, the gap between the overall level of education in places like these and that in developed areas will widen. In any case, if the local education situation in remote areas does not change and a sufficient number of schools with sufficient teachers are not built locally, it will be difficult for poor areas to narrow the gap with developed areas.

\subsubsection{China's Countermeasures}

In view of the education situation in remote areas, China's Ministry of education mainly took three measures: determining the number of people, investigating the reasons and ensuring enrollment. Besides, a series of policies or decrees have been formulated and issued, such as the Notice on Winning the Fight against Poverty and Further Improving the Work Related to Rural Compulsory Education, and the Work Plan on Solving the Outstanding Problems of Ensuring Compulsory Education for School-age Children of Poor Families. First of all, the Chinese government has carried out three large-scale verification of the number of dropout children in remote areas with the help of Internet resources such as the primary and secondary school student status system and the national population basic information database, and determined the identity information of dropout children through the online management platform of dropout control account. In Qinghai and Gansu provinces, for example, tens of thousands of officials were mobilized to confirm children's enrollment door-to-door. At the same time, online software was used to require all schools to publish student information on time.

Moreover, corresponding countermeasures have been established according to the different reasons for dropping out of school. Paying the fees for those who drop out of school for economic reasons. Establishing special courts in the local area for those who drop out of school because of inadequate law enforcement, etc.

As a result, the number of students dropped out of compulsory education in 832 national poor counties decreased from 290,000 at the end of May 2019 to 65,000 , and the number of students from recorded poor families decreased from 150,000 to 27,000 [1].

\subsection{Take some African and Latin American countries as examples}

\subsubsection{Education in South Africa}

As early as the 19th century, European countries had a very common understanding of the relationship between education and national strength, and South Africa, which was deeply influenced by Europe, was no exception.However, due to deep problems left over from the colonial era, such as apartheid, South Africa also suffers from educational inequality. Similar to China, there is a significant gap in education between developed and developing areas in South Africa. For most poor children, it is still unrealistic to receive the same education as students in middle-income and high-income areas, which is inseparable from the special national conditions of South Africa. Specifically, the long history of apartheid has brought about a huge gap between the rich and the poor. The implementation of "Bantu education" once prevented colored people unable to receive higher education, and it fundamentally cut off the possibility of competition between colored people and whites in terms of social status and income [3]. The social estrangement brought by these policies is difficult to eliminate easily.

In addition, the high tuition fees for higher education make poor families unable to afford. This phenomenon undoubtedly deprives poor students of their right to education in a disguised form. In 2015, the South African Ministry of Education announced an increase in college tuition fees, which can be confirmed by schools themselves (between zero and $8 \%$ ), which directly led to the outbreak of the "tuition fees must be reduced" movement in South Africa [4]. Perhaps, as the South African government claimed, the current education system was not problematic and unconstitutional in law. However, a legal system that can prevent poor students from obtaining the same education as students from middle-income and high-income families and even prevent them from completing their studies is clearly in violation of the provisions on the right to education in 
Article 26 of the Universal Declaration of human rights and Article 13 of the International Covenant on Economic, Social and Cultural Rights.

\subsubsection{South Africa's Countermeasures}

After the reform of South Africa in 1994, various laws and regulations with strong racial discrimination in the past were gradually abolished, and the South African government began to make many adjustments at the educational level. In terms of funds, education expenditure can account for an average of $20 \%$ of the total government expenditure, and even $30 \%$ in provinces with particularly underdeveloped education. In terms of teachers, during the apartheid period, all the excellent teachers in South Africa were often allocated to white schools. In view of this situation, South Africa issued the National Post Regulation Standard, which abolished the professional identity difference between white school teachers and black school teachers and uniformly classified them as "educators". On top of this, the allocation ratio of teachers in different regions was adjusted to allocate more teachers in less-developed areas [5].

\subsection{Education in Burkina Faso and Cuba}

As a country that just got independence from the French colonial government during the cold war, Burkina Faso's education situation is much worse than that of South Africa. During the socialist period, Burkina Faso carried out an extensive education campaign to increase the literacy rate from $6 \%$ to $18 \%$, and also introduced a plan to establish 350 community schools [6]. However, it was difficult for state finance to provide huge education expenditures. It could only reduce the budget of police and other public officials to subsidize education costs, which intensified social contradictions and brought social unrest.

Similar to China, Cuba is also a socialist country with a one-party system, and its educational system is roughly the same as that of China. As a Caribbean country, Cuba is unique in the area with its $99 \%$ literacy rate, universal free education system and high human development index, and there is no extreme poverty. Among Cubans aged 17 to $28,58 \%$ have received undergraduate education or above, about 520000 . Among the 11 million people, $7.14 \%$ have bachelor's degree or above. Equality in education, especially in higher education, has been valued in Cuba. The government does not recognize the classification of national universities according to their students' scores [7]. Moreover, professors in universities are required not only to engage in scientific research, but also to teach undergraduates. These measures have effectively controlled the widening of the education gap. In terms of basic education, according to the Cuban constitution, citizens enjoy equal right to education and compulsory nine-year education, regardless of gender and color. In response to the needs of Cuban children scattered in remote mountainous areas, the Cuban government has also opened more than 90 small schools that provide teaching only for a few students [8].

It is undeniable that Cuba has made considerable achievements in the education system and policy effectiveness. However, it is still uncertain whether such educational conditions can be maintained for a long time. Cuba is not a rich country, with a per capita GDP of 7980 pesos. Since the 21 st century, education funds have always maintained around $10 \%$ of the total economy [9]. Behind the impressive education data is a huge capital injection. After the economic crisis in 2008, Cuba gradually showed weakness in education funds: the average monthly salary of teachers was only $\$ 19$. Therefore, many teachers chose to change careers and go to higher paid industries such as tourism. In addition, the decline in the quality of education is the feeling of many Cubans and foreigners in Cuba: "For Cuba today, schools are far from enough. Sometimes the teacher's level is limited... I don't know how to explain the problem more clearly. I have to apply for extra-curricular counseling classes for my daughter. " "This is different from when I was young. At that time, you could get a good education in public schools. Now the material conditions of the school are very good and the curriculum is reasonable, but there are too few good teachers than before the economic crisis. " [10].

\section{ENLIGHTENMENT OF THE EDUCATION POLICIES}

\subsection{Faculty}

Education not only needs to play the main role of students, but also the leading role of teachers. In the rise of education in South Africa, the reform of the teacher system is an important part. The decline in the quality of education in Cuba is also inseparable from the leakage of excellent teachers. What is more, in recent years, Tibet and other places in China have also hired teachers from the developed cities, but the harsh living conditions and low salary in mountainous areas have made many teachers apply to leave after less than a year of teaching, which cannot play the due role of external teachers. Students' education is a long-term accumulation process.

From the experience of the places mentioned above, if there is a lack of enough excellent teachers from the primary school stage, it will be quite difficult for students to study in the junior middle school stage, let alone go to high school and university. Therefore, in terms of salary, the state should raise the salary level of teachers and avoid the outflow of excellent teachers to other industries. Referring to the Reform of the National 
Teacher Education Framework of South Africa on the treatment of teachers in remote areas and developed areas, the government needs to increase support for teachers in remote areas and improve the treatment of them, so as to encourage more excellent teachers to teach in remote areas.

\subsection{Funding}

From the experience of implementing education policies in many socialist countries or countries that implemented the socialist system before, it is not difficult to see that education development in remote areas is often difficult to last without sufficient capital injection. The collapse of universal education in Burkina Faso after the political turmoil of the 1980s and the decline in the quality of public education in Cuba after the economic crisis of 2008 was closely related to the problem of education funding. However, for China and other countries with good economic development momentum, the policies that cannot work well in Burkina Faso and Cuba do not mean that they are unfeasible policies. What is more, the inability of poor families to afford education has always been a major challenge for universal education. If education funding is not provided, parents living in remote areas are more likely to choose to send their children into the workplace to make money for the family rather than further their education.

In this regard, the government can regain the education policies interrupted by some countries, including increasing investment in teaching in remote areas, setting up schools, improving the road conditions around schools, adding teaching facilities, and paying all the school fees for school-age children. Referring to South Africa's National Standard for School Funding, $60 \%$ of the total government expenditure excluding personnel expenditure needs to be devoted to poor students. Furthermore, necessary monitoring measures, such as a funding flow review system, need to be established to ensure that the money is actually going where the education needs to go. For example, follow what the Chinese government did to establish an Internet supervision platform, timely requires schools to update relevant student information on the platform, and require officials to visit relevant families door to door to confirm the effectiveness of the countermeasures and ensure that the policies have indeed been implemented to those people in need.

\subsection{School}

For schools, if schools are sparsely distributed and each school is small, it is not conducive to the unified management of the government education department, but also may bring greater trouble to the local scarce teacher resources. For solving such a knotty issue,
Cuba's "one student's school" system [8] is worth learning from, integrating educational resources and setting up special schools so that children in remote areas can also enjoy the right to education.

From the perspective of the government education department, the number of schools and students in poor areas should be adjusted to local conditions, and these areas should not be hastily set the same school standards as those in developed areas. Educational resources should be integrated in time. For example, primary education schools can be concentrated in one place and secondary education schools can be concentrated in another place, so as to form "city of primary schools" and "city of middle schools" to avoid management difficulties caused by sparse distribution of schools.

\subsection{Idea}

Chinese President Xi Jinping once pointed out: " The fight against poverty should be combined with gaining intelligence and ambition of the people. " [11]. For remote areas, the development of education needs not only sufficient material conditions, but also changes in people's ideas. Therefore, education needs to reach not only school-age children, but also their elders. Ideological backwardness is a persistent problem accumulated for a long time, which is difficult to be eliminated by residents. The government needs to play a role in time and increase ideological construction, such as media promotion and regular collective education activities in remote areas, so as to make the elders of those children understand the relationship between education and poverty alleviation.

\section{CONCLUSION}

In this paper, an idea that the education in remote and poor areas is mainly influenced by four factors: teachers, funds, schools and ideas is proposed. Compared with traditional countermeasures, this paper emphasizes the combination of material education and spiritual education, and the combination of educating students and enlightening their guardians, ergo this kind of countermeasures have a chance to solve the problem more thoroughly. However, it is undeniable that policy is always only theoretical, and the development of education in different countries or regions tends to have different effects due to historical background, local culture and some other reasons. Therefore, in the specific practice of countering the backward development of education, measures must be taken according to local conditions and the development mode most conducive to the growth of local children should be selected. In addition, the countries and periods involved in this paper are limited. Further studies on education in other countries or regions also need to be carried out, and the implementation of educational 
policies under different historical backgrounds are also worth further study.

\section{ACKNOWLEDGMENTS}

First of all, in the process of writing this paper, I was under the guidance of Professor Gearon. He provided me with a lot of materials on education and international policies, helped me with the topic selection of my thesis, and gave me many suggestions, which benefited me a lot. I am very grateful to him for his patient teaching.

Secondly, I would like to thank Mr. Chen Chikai, who shared many books related to the article with me and offered constructive suggestions on the overall structure of my thesis.

In addition, I would like to thank my family and my school teachers for teaching me in many aspects of my life.

Finally, I would like to express my sincere thanks to all the other individuals who helped me in various ways during the completion of my thesis.

\section{REFERENCES}

[1] Xinhua News Agency(2019). Safeguarding the Right of School-age Children to Education -- An overview of the Work of Controlling dropout and ensuring school enrollment in China.

[2] Legislative Affairs Office of The State Council(2012). Education Code of the People's Republic of China.

[3] Hemann Giliomee(2012). Bantu Education: Destructive intervention or part reform?

[4] Chinese Social Science Network(2015). Protests at South Africa's universities demanding lower tuition fees have swept the country and alarmed President Jacob Zuma.

[5] GCIS(2005). South Africa Year Book 2005/06.

[6] Ministry of Foreign Affairs of the People's Republic of China(2019). Country profile of Burkina Faso.

[7] Jin Liang(2012). On the contemporary Cuban socialist system--Cuban Education under the socialist system.

[8] China Education(2005). Cuba: The best compulsory education in Latin America and even the world.

[9] Nationmeter.com.

[10] Southeast China morning post(2014). Public education deteriorates and private tutoring becomes popular.
[11] Qi Mingzheng, Shan Xuchang(2019). The idea and path of education to fight against poverty. 